\title{
Sanitation of Staphylococcus aureus genotype B-positive dairy herds: A field study
}

\author{
C. Sartori, ${ }^{*} †$ R. Boss, ${ }^{*} \ddagger$ M. Bodmer,§ A. Leuenberger, ${ }^{*}$ I. Ivanovic, ${ }^{*}$ and H. U. Graber*1 \\ *Agroscope, Food Microbial Systems, Group Microbiological Safety of Foods of Animal Origin, 3003 Berne, Switzerland \\ †ETH Zurich, Institute of Agricultural Sciences (IAS), Animal Physiology Group, 8092 Zurich, Switzerland \\ $\ddagger F e d e r a l$ Food Safety and Veterinary Office, 3003 Berne, Switzerland \\ §Vetsuisse Faculty, Department of Clinical Veterinary Medicine, Clinic for Ruminants, University of Berne, 3012 Berne, Switzerland
}

\section{ABSTRACT}

Staphylococcus aureus is one of the most widespread mastitis pathogens infecting dairy cattle worldwide. In Switzerland, different bovine genotypes of Staph. aureus have been identified, and genotype B (GTB) was demonstrated to be a highly contagious subtype, causing herd problems in cattle. As the efficacy of antibiotic therapy against Staph. aureus is not satisfactory, the most promising strategy for controlling this udder pathogen is the implementation of specific sanitation programs for affected farms. The aim of the present longitudinal study was the field evaluation of 2 analytical approaches for the sanitation of Staph. aureus GTBpositive dairy herds. We compared a new real-time quantitative PCR (qPCR) assay based on the detection of the unique target gene adlb with classical bacteriology. Sanitation was successfully achieved using both analytical methods, but the qPCR approach showed some main advantages, namely the use of clean (instead of aseptically collected) milk samples facilitates sample collection in terms of time and costs, enabling the sampling of entire herds during a regular milking procedure and by the farm staff. The high inclusivity and exclusivity of the new target gene adlb enable very specific detection of only the genotype of interest. Because of the very high diagnostic sensitivity of $\mathrm{qPCR}$, each GTB-positive cow can be correctly identified at any time point during lactation, allowing farmers to continuously update milking groups to prevent transmission during milking. Milk sample analysis becomes more objective, faster, less expensive, and more suitable for routine application, enabling the sanitation of even big herds in short time.

Key words: bovine mastitis, Staphylococcus aureus, sanitation, real-time quantitative PCR, classical bacteriology

Received October 4, 2017

Accepted March 27, 2018.

${ }^{1}$ Corresponding author: hansulrich.graber@agroscope.admin.ch

\section{INTRODUCTION}

Staphylococcus aureus is a major mastitis pathogen responsible for considerable economic loss to dairy farming worldwide (Halasa et al., 2009; Hogeveen et al., 2011). This very prevalent pathogen typically causes chronic, subclinical bovine IMI, but clinical forms are known (Petersson-Wolfe et al., 2010; Carrillo-Casas and Miranda-Morales, 2012). The milk of infected cows is generally characterized by higher SCC, and infection results in reduced milk quality and yield (Harmon, 1994; Carrillo-Casas and Miranda-Morales, 2012). Furthermore, Staph. aureus is able to produce a series of different heat-stable enterotoxins (Balaban and Rasooly, 2000), representing a risk factor for human health. Enterotoxin production starts when pathogens have reached a minimal concentration of $10^{5}$ to $10^{6}$ cfu/g in the raw milk (Paulin et al., 2011). Processing such milk to raw milk cheese could therefore result in products containing staphylococcal enterotoxins (Hummerjohann et al., 2014). The consumption of contaminated products can cause staphylococcal food poisoning, characterized by typical symptoms such as abdominal pain, nausea, vomiting, and diarrhea appearing about 0.5 to $8 \mathrm{~h}$ after ingestion (Balaban and Rasooly, 2000). The Swiss dairy industry is traditionally characterized by the production of raw milk cheese (Hummerjohann et al., 2014), and high quality of the raw milk is crucial to avoid food safety concerns.

According to a study conducted in Switzerland by Fournier et al. (2008), different genotypes of bovine Staph. aureus do exist, differing in their clinical, pathogenic, and epidemiological properties. Initially those authors identified 17 genotypes by PCR amplification of the 16S-23S rRNA intergenic spacer region, and the genotypes B (GTB) and C were found to be predominant in Swiss dairy herds, accounting for about $80 \%$ of the isolates. The remaining $20 \%$ of the Staph. aureus isolates belonged to other genotypes. The quarter- and cow- prevalence was found to strongly depend on the genotype infecting the cows: Staph. aureus GTB typi- 
cally causes herd problems, whereas genotype C and other genotypes are responsible for sporadic infections of single cows and quarters (Fournier et al., 2008). Similar results were observed in a recent study by Cremonesi et al. (2015), investigating the genomic characteristics of Staph. aureus strains associated with high within-herd prevalence of bovine IMI in Italian dairy herds.

The estimated herd prevalence for Staph. aureus GTB in Switzerland is about 10\%, with local clusters (Cosandey et al., 2016). Voelk et al. (2014) investigated the within-herd prevalence of Staph. aureus GTB on several Swiss communal summer pastures and revealed a prevalence of up to $72 \%$ among the cows on 1 alpine communal operation at the end of the summer season. The same study showed that the within-herd prevalence on alpine operations increased rapidly over the time, providing further evidence for the contagious nature of Staph. aureus GTB. The contagiousness of Staph. aureus GTB was also confirmed by van den Borne et al. (2017), who aimed to quantify transmission in Staph. aureus GTB-positive alpine communal operations. In a study by Kümmel et al. (2016), investigating the ability to enter the food chain, Staph. aureus GTB was demonstrated to be the genotype most successfully transmitted from the bovine udder to milk processing chain and cheese. This finding was further supported by a study conducted in Switzerland by Hummerjohann et al. (2014), where GTB was found to be the most abundant Staph. aureus genotype isolated from raw milk cheese.

Because of the low cure rates achieved by antibiotic treatment of Staph. aureus IMI in single cows (Sol et al., 1997; Sol et al., 2000; Gruet et al., 2001; Sears and McCarthy, 2003; Barkema et al., 2006) and the limited effectiveness of vaccination to prevent new Staph. aureus infections (Peton and Le Loir, 2014; Schukken et al., 2014; Landin et al., 2015), the implementation of sanitation programs is currently the most reasonable approach to control Staph. aureus in positive herds. Based on the original 5-point plan by Neave et al. (1969), various mastitis control programs were developed in different European countries [e.g., Norway (Osterås and Sølverød, 2009), Switzerland (Kirchhofer et al., 2011), and the Netherlands (Lam et al., 2013)] aiming to control this disease on dairy farms. These studies, together with the 10-point Mastitis Control Program of the National Mastitis Council (NMC; http://www.nmconline.org/wp-content/uploads / 2016/08/RECOMMENDED-MASTITIS-CONTROL -PROGRAM-International.pdf) represent the foundation for the sanitation program for Staph. aureus GTB presented in this paper.

An additional crucial point for the control of mastitis pathogens is the method used for their detection in milk. Classical, phenotypical bacteriology represents the gold standard method currently used for analysis of aseptically collected milk samples (Koskinen et al., 2010). In addition to longer test time and interpretation issues (Koskinen et al., 2010), culturing methods have a low diagnostic sensitivity for Staph. aureus. To increase sensitivity, 3 consecutive analyses of milk samples are necessary (Sears et al., 1990; Studer et al., 2008). Therefore, the minimum time required to clarify the status of a cow is $1 \mathrm{mo}$, considering time intervals of 2 to 3 wk between samplings (Kirchhofer et al., 2011). Repeated sampling is required due to the known cyclic shedding pattern of Staph. aureus from infected mammary glands (Sears et al., 1990; Studer et al., 2008). Additionally, classical bacteriology does not enable to differentiate between different genotypes of Staph. aureus. Therefore, novel molecular biology methods based on real-time quantitative PCR (qPCR) were developed to overcome this limitation. In particular, the assays by Boss et al. (2011) and Syring et al. (2012) were developed for the specific detection of Staph. aureus GTB in milk. Both based on the parallel detection of 3 targets, coding for a SNP in the leucotoxin E (lukE) gene, and for the 2 enterotoxin genes sea and sed. The novel qPCR assay by Sartori et al. (2017), however, enables the very specific detection of GTB of Staph. aureus based on the unique target gene adlb. The assay is suitable for high-throughput analysis and represents a robust test for the detection of Staph. aureus GTB in bovine milk samples. It shows very high analytical specificity (inclusivity and exclusivity) and a low limit of detection. Furthermore, it shows an excellent diagnostic sensitivity $(99 \%, 95 \% \mathrm{CI}= \pm 2)$ and specificity $(100 \%, 95 \% \mathrm{CI}= \pm 2)$. Because of these excellent characteristics, and the shorter time required between sample collection and the final result, qPCR assays are among the most promising techniques for the detection of mastitis pathogens in milk (Koskinen et al., 2010). Furthermore, sampling under clean conditions is sufficient regarding sample quality and can be done by the farmer, compared with sampling for microbiology that requires a trained technician and aseptic conditions. These advantageous properties are of particular interest to monitor dairy herds undergoing a sanitation program for the contagious mastitis-associated pathogen Staph. aureus GTB (Sartori et al., 2017).

The aim of the present study was therefore to evaluate the performance of the new qPCR assay by Sartori et al. (2017) for the sanitation of Staph. aureus GTBpositive dairy herds in the field. In brief, the new qPCR assay was compared with classical bacteriology as the gold standard for detection of Staph. aureus GTB in milk samples, and both methods were evaluated for their efficiency in terms of sanitation success, sampling technique, test time, and costs. The 2 specific topics 
antibiotic therapy and SCC course during a sanitation program for Staph. aureus GTB are described in this paper as an overview and will be handled in more detail in further studies.

\section{MATERIALS AND METHODS}

\section{Selection of Herds and Inclusion Criteria}

Dairy herds were selected with the help of the official laboratory for milk quality testing in Switzerland (Suisselab AG, Zollikofen, Switzerland), which sent to all farmers with recurrent Staph. aureus-positive results in the past year an informative letter containing a brief description of our project. Interested farmers were free to contact us asking for additional information. Furthermore, practicing veterinarians supported our search for GTB-positive herds among their clientele based on their knowledge on the farm history. The bulk tank milk (BTM) of each farm was tested for the presence of Staph. aureus GTB using the new qPCR assay by Sartori et al. (2017). Cows not milked in the tank were individually tested and involved in the farm's outcome.

Inclusion criteria for the participation in the study were a Staph. aureus GTB-positive BTM and the willingness of the farmers to respect the principles of the presented sanitation program. Additionally, farmers had to be part of an official milk recording scheme and make their monthly SCC results of all lactating cows available to us to monitor this parameter during the sanitation period. All types of milking system were accepted for the field study except automatic milking systems, as they preclude the possibility to keep a milking order, which represents a crucial point in the sanitation program.

\section{Study Design}

In total, 21 GTB-positive dairy herds were included in the field study. During a pilot phase directly preceding the start of the official field study, 2 dairy herds were used as pilot herds to test and adapt the qPCRbased sanitation procedure, as no experience had been acquired before in using this new approach in practice. A further 19 farms were selected and randomly allocated to 1 of 2 sanitation groups (bacteriology or qPCR group) by flipping a coin. If 2 farms were located in the same geographic region and followed by the same veterinarian, they were attributed to different groups to avoid selection bias.

The 2 sanitation groups differed in the analytical method used for milk sample analysis, including different milk sampling types and frequencies, but both groups were subjected to identical sanitation measures for 9 mo after the 1st sampling. Decisions during the sanitation program (milking order, therapies, culling) were taken based on qPCR results for herds of the qPCR group and on bacteriology results for herds of the bacteriology group.

On farms of the qPCR group, composite milk samples were collected from each lactating cow under clean conditions at monthly intervals (9 samplings in total) and analyzed for Staph. aureus GTB by qPCR (Figure 1). On farms of the bacteriology group, single-quarter milk samples were aseptically collected 6 times from each lactating cow and samples were analyzed for Staph. aureus by classical bacteriology (Figure 1 ). For the initial evaluation of each cow at the beginning of the study, these herds were consecutively analyzed 3 times at intervals of 2 to 3 wk (samplings 1, 1.2, and $1.3=$ initial triple sampling) to maximize the diagnostic sensitivity of bacteriological culturing for Staph. aureus (Sears et al., 1990; Studer et al., 2008; Kirchhofer et al., 2011). A further 3 samplings followed at intervals of 3 mo after the end of the initial triple sampling (corresponding to sampling 3,6, and 9 of the qPCR group). Samples from sampling 1, 3, 6, and 9 were additionally analyzed by qPCR, resulting in 4 GTB-prevalence values for farms of the bacteriology group (Figure 1). Furthermore, an additional measure was taken to make up for the longer time intervals between samplings of herds of the bacteriology group. Any SCC values above 150,000 cells/ $\mathrm{mL}$ were considered signal for a potential new infection, and we recommended to farmers of the bacteriology group to send to our laboratory sterile milk samples of each cow showing SCC >150,000 cells/mL during the last official monthly control for bacteriological analysis. This optional measure enabled us to equilibrate the different sampling frequencies of the 2 sanitation groups, giving an equal opportunity to farmers of both groups to sanitize their herds. After the end of the study, monitoring the GTB status of their herds by analyzing milk samples using the qPCR method was offered to the farmers of both sanitation groups.

\section{Sanitation Measures - Milking Procedures}

Independent of the sanitation group, all farmers were advised to follow several sanitation measures, which were advantageous in previous mastitis control programs (Neave et al., 1969; Osterås and Sølverød, 2009; Kirchhofer et al., 2011; Lam et al., 2013; 10-point Mastitis Control Program of the NMC, International Version: http://www.nmconline.org/wp-content/uploads/ 2016/08/RECOMMENDED-MASTITIS-CONTROL -PROGRAM-International.pdf). Some points were strictly mandatory, whereas other points were recommended but facultative. The most important manda- 


\begin{tabular}{|c|c|c|c|c|c|c|c|c|c|}
\hline \multicolumn{10}{|l|}{ qPCR } \\
\hline sampling & 1 & 2 & 3 & 4 & 5 & 6 & 7 & 8 & 9 \\
\hline \multirow{2}{*}{$\begin{array}{l}\text { Bacteriology } \\
\text { sanitation group }\end{array}$} & qPCR & & $\mathrm{qPCR}$ & & & qPCR & & & qPCR \\
\hline & $\begin{array}{l}\text { bacteri } \\
(1,1.2, \\
\text { initial tr }\end{array}$ & amplin & \multicolumn{3}{|c|}{ bacteriology } & \multicolumn{3}{|c|}{ bacteriology } & bacteriology \\
\hline
\end{tabular}

Figure 1. Schedule of sampling and testing for herds of the real-time quantitative PCR (qPCR) group, and herds of the bacteriology group during a sanitation field study for Staphylococcus aureus genotype B.

tory point was (1) sticking to a strict milking order based on the current GTB status of the animals in the herd. Milking group 1 (GTB-negative cows) was always milked first, followed by milking group 2 (including all cows with an unknown GTB status (e.g., cows directly after calving, after an antibiotic mastitis therapy or new in the herd). Only cows tested negative for Staph. aureus (GTB) during at least 2 consecutive samplings after calving, therapy, or purchase could be moved from milking group 2 to milking group 1. Milking group 3 (GTB-positive cows) was milked last. The assignment of cows to milking groups was updated after each sampling. Further mandatories were (2) proper cleaning of the milking equipment (washing of the milking clusters after each milking of the herd according to the manufacturer's guidelines); (3) single-use material (e.g., wood wool or humid disinfectant towels or both) for cleaning udder and teats before milking; (4) postmilking teat disinfection; and 5) maintenance of the milking system once a year by a specialized and authorized operator. Foremilking in a premilking cup and wearing gloves during milking were recommended but optional procedures.

\section{Antibiotic Mastitis Therapy}

The antibiotic therapy of GTB-positive cows (during lactation or the dry period or both) was a facultative but important measure, and was therefore strongly suggested during the sanitation program. A standardized lactation therapy was selected and recommended until 200 DIM. Lactation therapy consisted of a local administration of a combination of cephalexin and kanamycin (Ubrolexin; Boehringer Ingelheim, Ingelheim am Rhein, Germany) for $5 \mathrm{~d}$ in intervals of $24 \mathrm{~h}$ to all 4 quarters of each GTB-positive cow. As a principle, antibiotic treatment was recommended for all GTB-positive cows, with first priority for young cows (1st and 2nd lactation) showing low SCC and early in lactation, followed by those with high SCC, later in lactation, and in higher lactations. A further recommendation was the culling of therapy-resistant cows (i.e., those remaining GTB-positive after a lactation or dry cow therapy or a combination of both), whereas the culling of pregnant cows was always strongly discouraged. Blanket dry cow therapy was recommended for all herds during sanitation, but the choice of the administered drug was in the responsibility of the private veterinarians.

\section{Collection of Additional Data}

A subjective farm evaluation (SFE) value ranging from 1 (poor milking management and low farmer commitment) to 3 (good milking management and high farmer commitment) was attributed to each farm at the end of the program, but before statistical data analysis (Table 1). This value included 2 components, (1) the first impression of the farm after the first visit (in particular, evaluation of the milking procedure and of the general hygiene of the farm) and (2) the commitment of the farmer during the whole sanitation program in following the proposed measures (in particular, milking order and hygiene, treatment and culling of infected cows). Monthly SCC data were made available for each farm during the whole sanitation period from the 2 Swiss breeding associations (Braunvieh Schweiz, Zug, Switzerland, and swissherdbook, Zollikofen, Switzerland).

\section{Collection and Storage of Milk Samples}

Milk samples were collected from individual cows after preparation but before milking. Sampling was carried out during the evening milking, with the few exceptions of herds being sampled during the morning milking. After collection, milk samples were stored at $4^{\circ} \mathrm{C}$ for analysis within $1 \mathrm{wk}$ or at $-20^{\circ} \mathrm{C}$ for later analysis. No preservative substances were added to 
the milk samples after collection. After milk sample analysis, samples were stored at $-20^{\circ} \mathrm{C}$ until the end of study.

Milk Sampling for Bacteriological Analysis. Samples for bacteriological analysis were collected aseptically, according to the guidelines of the NMC (http:// www.nmconline.org/wp-content/uploads/2016/09/ Procedures-for-Collecting-Milk-Samples.pdf) by a trained technician. Cow udders and teats were roughly cleaned to eliminate dirt and bedding material using wood wool or humid, single-use disinfectant towels or both. After having discarded the first milk streams of each quarter in a premilking cup, teat ends and orifices were thoroughly disinfected using gauze soaked in $70 \%$ ethanol. Single-quarter milk samples were then individually collected in sterile 10 -mL plastic tubes.

Milk Sampling for qPCR Analysis. Samples for qPCR analysis were collected under clean conditions by a trained person, or by the milking personnel, and sent to the laboratory by priority post. Cleaning procedure before milking was performed by the farm personnel, as usually done. After having discarded the first milk streams of each quarter, milk of all quarters of a cow was collected in approximately equal amounts into a sterile $50-\mathrm{mL}$ plastic tube.

\section{Milk Sample Analysis}

Prior to analysis, milk samples were prewarmed to $37^{\circ} \mathrm{C}$ in a water bath and vortexed to obtain a homogeneous suspension.

Classical Bacteriological Analysis. For bacteriological analysis, $10 \mu \mathrm{L}$ of milk were plated on blood agar (BA) plates (Biomérieux Suisse s.a., Geneva, Switzerland), using a sterile, single-use plastic loop. A 3 -streak technique was used, allowing the isolation of single colonies. The BA plates were aerobically incubated at $37^{\circ} \mathrm{C}$ and evaluated after 24 and $48 \mathrm{~h}$ of incubation. Bacterial growth was assessed for each individual species as follows. Plates showing less than 10 colonies were marked with "+," plates with 11 to 30 colonies with "++," and plates with more than 30 colonies with "+++." Cultures showing no growth were marked as sterile. Milk cultures showing more than 3 morphologi-

Table 1. Dairy herds included in the sanitation field study for Staphylococcus aureus genotype B (GTB) comparing real-time quantitative PCR (qPCR) and classical bacteriology as analytical methods

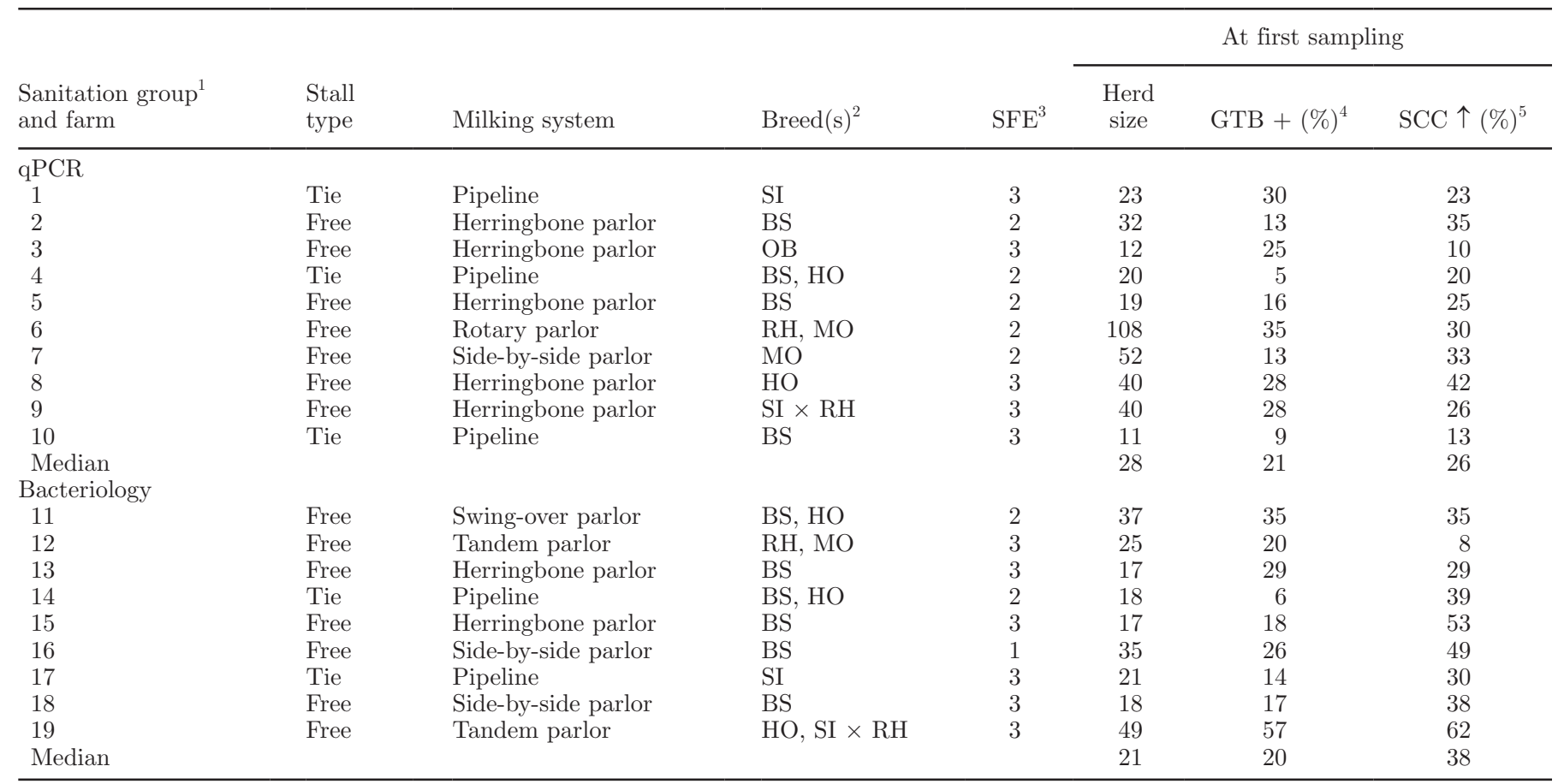

${ }^{1} \mathrm{qPCR}=$ sanitation group in which milk was analyzed by qPCR; Bacteriology = sanitation group in which milk was analyzed by bacteriology. ${ }^{2} \mathrm{SI}=$ Simmental; BS = Brown Swiss; OB = Original Brown; HO = Holstein; RH = Red Holstein; MO = Montbéliarde.

${ }^{3}$ Subjective farm evaluation (SFE) value, ranging from 1 (poor milking management and low farmer commitment) to 3 (good milking management and high farmer commitment).

${ }^{4} \mathrm{GTB}+$ : percentage of cows positive for Staph. aureus GTB (within-herd GTB prevalence) at first sampling.

${ }^{5} \mathrm{SCC} \uparrow$ : percentage of cows with $\mathrm{SCC}>150,000$ cells/mL at first sampling. 
cally different bacterial species were defined as mixed flora and were excluded from further bacteriological analysis because a contamination was most likely.

Milk samples were analyzed according to the Laboratory Handbook on Bovine Mastitis of the NMC (1999). The morphology of colonies and eventual hemolysis on BA was evaluated by a specialist. For each bacterial culture requiring confirmatory tests, 1 typical colony per plate was additionally analyzed by 1 or more of the following tests. The catalase test was performed to discriminate between staphylococci (catalase-positive) and streptococci (catalase-negative). To differentiate between Streptococcus agalactiae and other streptococci, the Christie, Atkins, and Munch-Petersen test (CAMP test) was performed. In case of doubt, Gram staining was additionally carried out. After $24 \mathrm{~h}$ of incubation of the BA plates, presumptive Staph. aureus (1 typical colony per plate) were subcultured on CHROMagar Staph. aureus (CHROMagar, Paris, France); Staph. aureus colonies were characterized by a mauve coloration on this medium.

Based on our bacteriological analyses, a definitive result at the species level was possible for the 2 contagious mastitis pathogens Staph. aureus and Strep. agalactiae. Other staphylococci and streptococci were differentiated at the genus level.

As bacteriology does not allow conclusions regarding genotypes, milk samples of the bacteriology group were additionally analyzed by qPCR in a 3-mo interval for comparison of the GTB prevalence in the 2 sanitation groups. To this purpose, $125 \mu \mathrm{L}$ of each single-quarter milk sample were pooled to form a composite sample of each cow that was then processed identically as described for the qPCR group.

qPCR Analysis Procedure. The analysis was performed as described by Sartori et al. (2017). In brief, milk samples were first enriched in Chapman medium $[10 \mathrm{~g} / \mathrm{L}$ of casein-peptone (Merck AG, Zug, Switzerland), $1 \mathrm{~g} / \mathrm{L}$ of Lab-Lemco powder (Oxoid, Pratteln, Switzerland), $75 \mathrm{~g} / \mathrm{L}$ of $\mathrm{NaCl}$ (Merck AG), $10 \mathrm{~g} / \mathrm{L}$ of Dmannitol (Sigma-Aldrich Chemie GmbH, Buchs, Switzerland)], which is selective for staphylococci. Cultures were prepared by adding $500 \mu \mathrm{L}$ of milk to $4.5 \mathrm{~mL}$ of Chapman medium, and then aerobically incubated for $18 \mathrm{~h}$ at $37^{\circ} \mathrm{C}$ under constant shaking (160 rpm). The DNA extraction from cultures was performed using the Mericon DNA Bacteria Plus Kit (Qiagen AG, Hombrechtikon, Switzerland), following the instructions (https://www.qiagen.com/us/resources/resourcedetail ?id=8a513dcc-dfc3-4101-bdb3-3f846b68ba87\&lang = en) of the manufacturer. In particular, $1 \mathrm{~mL}$ of enriched bacterial culture was added to $650 \mu \mathrm{L}$ of extraction mix (containing $150 \mu \mathrm{L}$ of Lactobacillus casei, $10^{10} \mathrm{cfu} / \mathrm{mL}$, $300 \mu \mathrm{L}$ of Triton X-100, $2 \%$, and $200 \mu \mathrm{L}$ of Tris/HCl
$100 \mathrm{mM}, \mathrm{pH}=7.8)$ and centrifuged for $5 \min (18,000$ $\left.\times g, 4^{\circ} \mathrm{C}\right)$. The supernatant was then discarded using a vacuum pump, and the pellet resuspended in $400 \mu \mathrm{L}$ of Fast Lysis Buffer (Qiagen). Samples were transferred into Pathogen Lysis Tubes (Qiagen) containing glass beads, which were then horizontally vortexed for 10 min at maximal speed. Finally, samples were centrifuged for $5 \mathrm{~min}\left(13,000 \times \mathrm{g}, 25^{\circ} \mathrm{C}\right)$, and $100 \mu \mathrm{L}$ of the supernatant containing the extracted DNA were transferred in the final tubes and either directly used as template for $\mathrm{qPCR}$ analysis or stored at $-20^{\circ} \mathrm{C}$ until further use.

A positive and a negative process control were always co-processed with every new series of milk samples, including all steps of the analytical procedure (enrichment, DNA extraction, and qPCR). Raw milk spiked with $10^{5}$ staphylococcal cell equivalents/mL of Staph. aureus GTB was used as positive control, and raw milk negative for Staph. aureus was used as negative control.

The qPCR analysis was based on the detection of the unique target gene $a d l b$ according to Sartori et al. (2017). For each DNA sample, a single qPCR reaction was performed, and for each run a positive and a no-template control were co-analyzed, as well as the internal amplification control for each sample (Sartori et al., 2017). Results were considered positive for Staph. aureus GTB if the cycle threshold (Ct) for adlb was $<21.8$, corresponding to $9.25 \times 10^{4}$ copies/reaction (Sartori et al., 2017).

\section{Within-Herd Prevalence of Staph. aureus GTB During Sanitation}

The within-herd prevalence of Staph. aureus GTB was calculated considering the qPCR results for both sanitation groups, and is given in percentage (number of GTB-positive cows/total number of cows sampled). For comparison of the GTB within-herd prevalence in both sanitation groups, samples from sampling 1, 3, 6 , and 9 of the bacteriology group were additionally analyzed by qPCR for adlb (see above) in a 3-mo interval. These results were compared with the results of the qPCR group at the same interval. The independent variables considered in the logistic regression for the infection rate (dependent variable $=$ GTB-prevalence) were (1) the analytical method used for milk sample analysis, (2) the SFE, (3) the herd size, and (4) the initial GTB-prevalence on farm.

For cows of the bacteriology group, the following definitions should be considered when comparing bacteriology and $\mathrm{qPCR}$ results for the samplings 1, 3, 6, and 9. A false-negative result was given by a cow showing no growth for Staph. aureus by bacteriology, but being positive for Staph. aureus GTB by qPCR. A 
false-positive result was given by a cow showing growth for Staph. aureus by bacteriology, but being negative for Staph. aureus GTB by qPCR.

\section{GTB-Specific Cure and Culling Rates of Infected Cows}

The 2 parameters GTB-specific cure rate and culling rate of infected cows were defined and calculated as follows. The GTB-specific cure rate was the percentage of successfully treated cows among all GTB-positive cows treated during the sanitation study. Successfully treated defines cows showing GTB-negative results during at least 2 consecutive months after lactation or dry cow therapy; the cure rate was calculated per farm and overall (considering all farms together). The GTB-specific culling rate was calculated for each herd separately by dividing the number of cows culled (because GTB-positive) by the total number of cows tested positive for Staph. aureus GTB over all samplings (cows sampled positive several times were only counted once).

\section{SCC During Sanitation}

For all herds participating to the field study, the theoretical bulk milk somatic cell count (BMSCC) was calculated in 3-mo intervals for samplings 1, 3, 6, and 9 (Figure 2). This parameter corresponds to the arithmetic mean of the SCC of all lactating cows on each farm at the time of sampling. For the evaluation of the BMSCC of each herd over the sanitation time, SCC of cows with acute mastitis caused by pathogens other than Staph. aureus GTB were excluded after a bacteriological clarification of the causative organisms.

\section{Comparison of Testing Time and Detection Cost for GTB in Milk by qPCR and Bacteriology}

A comparison of the analysis time and cost was made for the first evaluation of a median Swiss dairy herd of 25 cows (http://milch-umwelt.swissmilk.ch/issue/ familienbetriebe/) by simulating all analytical steps (from cow sampling to the end result) for both analytical methods (qPCR, classical bacteriology). The time required to perform each analytical step was timed by means of a chronometer. The total cost for both methods was calculated considering the sum of cost for material and personnel, whereas the costs of infrastructure and facility were not included in the calculations. The amortization costs of the qPCR machine [value: CHF20,000, where 1 Swiss franc $(\mathrm{CHF})=$ US\$1.01] were calculated for a currently running GTB sanitation program including 200 dairy herds and with program duration $=3 \mathrm{yr}$, analysis of 50 samples/working day,
5 working days/week, and 30 working weeks/year. The total cost of material was calculated considering the actual commercial prices for all consumables and reagents used. Average Swiss hourly rates were considered for the calculation of the cost of personnel, specifically CHF $30 / \mathrm{h}$ for a laboratory technician (analytical work), CHF50/h for a specifically trained laboratory technician (aseptic milk sampling), and CHF200/h for a specialist (veterinarian, microbiologist) for the definitive evaluation of bacterial cultures.

\section{Data Analysis}

Data were expressed as frequencies or presented as median, minimum, and maximum. The GTB infection rate at different points in time was modeled by logistic regression initially using the binomial model together with a correction (over-dispersion method) for correlations among the included variables. Later analysis showed, however, that this correction was not necessary; thus, it was excluded in the final model. The GTB infection rate was modeled as a function of the method used for milk analysis ( $\mathrm{qPCR}=1$, bacteriology $=0$ ), the SFE, the herd size, and the initial GTB-prevalence on farm. Computation was performed using the GLM function implemented in the R 3.4.1 software (R Core Team, 2017). If not otherwise stated, statistical data evaluation was performed using the Systat 13.1 software (Systat Software, San Jose, CA). Significance was defined at $P<0.05$.

\section{RESULTS}

\section{Pilot Herds}

During the pilot phase, 3 main phenomena were observed and considered during the official study to adapt and optimize the sanitation procedure to avoid new infections. The first phenomenon was that of cows being transiently positive for Staph. aureus GTB during the first 2 mo after parturition, and then negative for the rest of lactation without having been subjected to any antibiotic treatment. The second phenomenon was that of cows being transiently GTB-positive during the last 1 to 2 mo before drying off, but never before. The third phenomenon was that of GTB-positive cows showing low SCC $(<100,000$ cells $/ \mathrm{mL})$ during several consecutive months despite infection.

\section{Characterization of Herds}

A total of 19 dairy herds were evaluated in the sanitation field study for Staph. aureus GTB between October 2013 and September 2017 (Table 1). Ten of them 


\section{FARM}
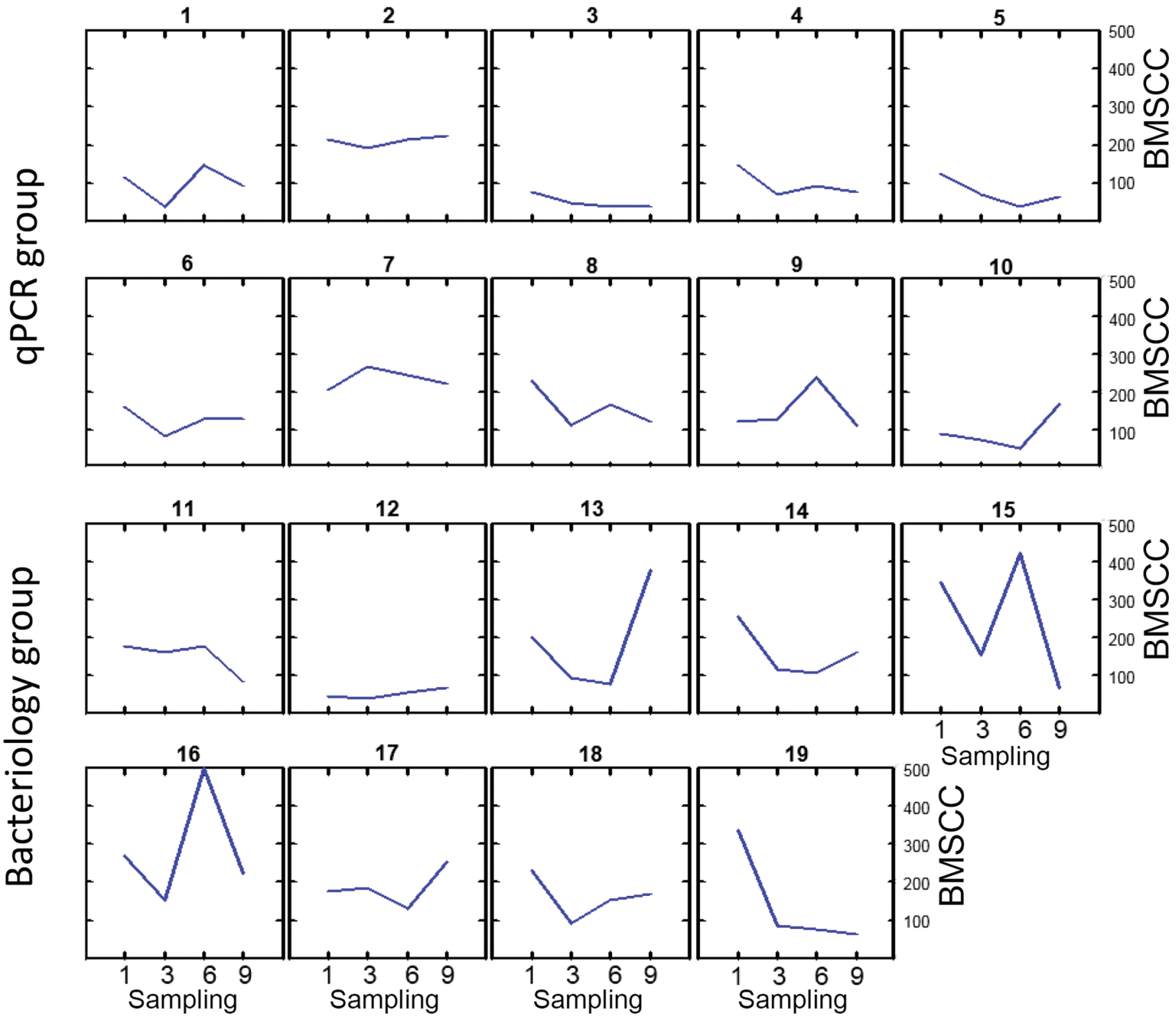

Figure 2. Theoretical bulk milk somatic cell count (BMSCC) course of all farms participating in the sanitation field study for Staphylococcus aureus genotype B. Farms 1 to 10 belonged to the real-time quantitative PCR (qPCR) group; farms 11 to 19 belonged to the bacteriology group. BMSCC values $\left(\times 10^{-3}\right.$ cells $\left./ \mathrm{mL}\right)$ are given on the y-axis for the samplings $1,3,6$, and 9 . Color version available online.

were allocated to the qPCR group and 9 of them to the bacteriology group. Herds were distributed all over Switzerland, including the cantons of Bern, Graubünden, Jura, Luzern, Obwalden, Ticino, Uri, and Zürich. Both types of housing systems were represented in each sanitation group (Table 1): the qPCR group included 7 freestalls and 3 tiestalls, whereas the bacteriology group included 7 freestalls and 2 tiestalls. All relevant milking systems (pipeline, herringbone, rotary, side- by-side, swing-over, and tandem parlor) and national cow breeds (Brown Swiss, Original Brown, Simmental, Holstein, Red Holstein, and Montbéliarde) were represented (Table 1). Alpine pasturing during the summer season (June until September) was carried out by farms $1,4,9$, and 10 of the qPCR group and by farms 11 , $13,14,15,16,17$, and 18 of the bacteriology group. Considering all farms of both sanitation groups at 1st sampling (Table 1), the herd size ranged from 11 to 108 
cows, with a median of 23 . Additionally, at 1st sampling, the median prevalence of Staph. aureus GTB was $20 \%$ (5-57\%), and the median percentage of cows with $\mathrm{SCC} / \mathrm{mL}>150,000$ was $30 \%(8-62 \%)$. Both maximal values were achieved by farm 19 (Table 1).

\section{Within-Herd Prevalence of Staph. aureus GTB During Sanitation}

$\boldsymbol{q P C R}$ Group. All farms of the qPCR group could be sanitized within the 9-mo sanitation period (Table 2). A zero prevalence for Staph. aureus GTB was first obtained at sampling 2 (farms 1 and 10) and last at sampling 8 (farms 4,6 , and 8). On farms 2, 6, 7, and 9 , the GTB prevalence decreased progressively during the sanitation time. On farms 4 and 8, the overall GTB prevalence decrease was interrupted by an increase during the sanitation time (Table 2). On farm 8, the GTB prevalence increased between the samplings 4 and 5 from 3 to $7 \%$ (corresponding to $1 / 36$ and $3 / 41$ GTBpositive cows, respectively). Farm 4 still showed a GTB prevalence of $22 \%$ (corresponding to 7 GTB-positive cows out of 32) at sampling 7 , after a prevalence increase between the samplings 6 and 7 .

Bacteriology Group. Six out of 9 farms could be sanitized within the 9-mo sanitation period (Table 2): 5 of them reached a zero prevalence for Staph. aureus GTB at sampling 3 (farms 12, 13, 14, 15, and 18), whereas farm 19 reached sanitation at sampling 9 after a strong decrease of the GTB prevalence between samplings 1 and 3 (from 57 to $5 \%$, corresponding to 28/49 and 2/43 GTB-positive cows, respectively). Three farms could not be sanitized until the end of the sanitation time, and 2 farms (farms 11 and 17) showed a progressive decrease of the GTB prevalence over the sanitation time and reached a very low prevalence at last sampling (5\%, corresponding to 2 and 1 GTBpositive cows for farm 11 and 17, respectively). Farm 16 was characterized by an increased GTB prevalence at samplings 6 and 9 (12 and 21\%, corresponding to 4/34 and 6/28 GTB-positive cows, respectively), whereas it had decreased from sampling 1 to 3 (from 26 to $4 \%$, corresponding to $9 / 35$ and 1/26 GTB-positive cows, respectively).

Statistical Evaluation. At the 1st sampling, both the distribution of the GTB prevalence values and the relative median were comparable for both sanitation groups (Table 1). At samplings 3 and 6 , none of the independent variables (analytical method used for milk sample analysis, farmer attitude toward the sanitation program, herd size, and initial GTB-prevalence on farm) considered in the logistic regression for the infection rate showed a significant effect on the GTB prevalence. At sampling 9, the variable farmer attitude showed a highly significant effect on the GTB prevalence $(P<0.001)$. In fact, farms characterized by a lower SFE value (1 or 2) were either slower (farm 4) or unable (farms 11 and 16) to reach a GTB prevalence of zero until the end of the official sanitation time.

Comparison of Sanitation Results for Herds of the Bacteriology Group. On 4 out of 9 farms, identical results could be obtained for all compared samplings $(1,3,6$, and 9$)$ by classical bacteriology and qPCR (farms 12, 13, 17, and 18). Discrepancies between the 2 methods could be observed for the remaining 5 farms. A false-negative result was given by a cow of the bacteriology group positive for Staph. aureus GTB by $\mathrm{qPCR}$ and showing no growth for Staph. aureus by bacteriology. False-negative results were found on 3 farms: on farms 11 and 19 this was the case for each 1 cow and on farm 16 this concerned a total of 4 cows. A false-positive result was given by a cow of the bacteriology group negative for Staph. aureus GTB by qPCR and showing growth for Staph. aureus by bacteriology. False-positive results were found on 3 farms. On farm 11, this was the case for a total of 13 cows. On farm 14, this concerned a total of 9 cows, with 2 of them being false positive both at the initial and at the sampling 6 . On farm 15, a total of 3 cows were false positive, and 2 of them were false positive both at the initial and at sampling 3 or 6 , respectively.

\section{GTB-Specific Cure and Culling Rates of Infected Cows}

The GTB-specific cure rates varied between 63 and $100 \%$ in our study, depending on the farm (Table 3). Considering the total number of cows treated with antibiotics during lactation or the dry period, the overall cure rate was $93 \%$. Considering the culling rate of all GTB-positive cows per farm, the median rate was $17 \%$, ranging from 0 to $71 \%$ (Table 3 ). The median culling rate was $20 \%$ for the qPCR group and $14 \%$ for the bacteriology group (Table 3).

\section{SCC During Sanitation}

Different patterns could be observed in the BMSCC of the different farms over the sanitation time (Figure 2). Farms 3 and 12 showed BMSCC values lower than 80,000 cells $/ \mathrm{mL}$ during the whole sanitation time. As expected, farms 4, 5, 6, 8, 11, and 19 showed an overall decrease of their BMSCC, particularly toward the end of the sanitation time (Figure 2). In contrast, farms $1,2,7,9,10,13,14,15,16,17$, and 18 showed an unexpected BMSCC course over the sanitation time (Figure 2). Farms 2 and 7 showed median BMSCC values always above 200,000 cells/mL. Farm 9 showed a 
SARTORI ET AL.

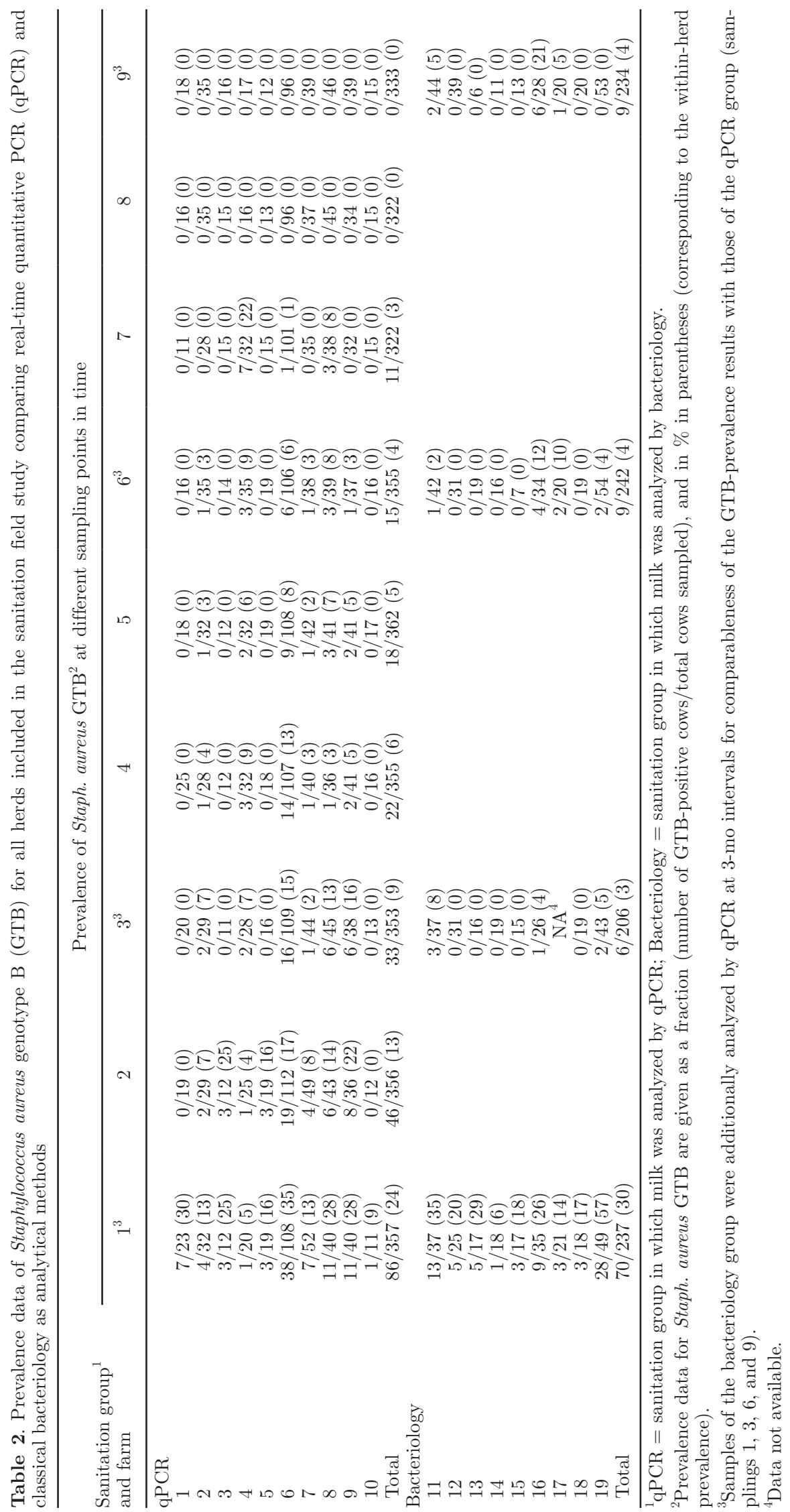


peak at sampling 6 , which corresponded to the start of the alpine season. The remaining farms showed marked peaks in their BMSCC values at the end of the alpine season, which corresponded to sampling 6 for farms 1 , 15, and 16, and to sampling 9 for farms 10, 13, 14, 17, and 18 (Figure 2).

\section{Comparison of Testing Time and Detection Cost for GTB in Milk by qPCR and Bacteriology}

The total labor time (including preparation, milk sampling, and laboratory work) required for a complete first evaluation of a median Swiss dairy herd $(\mathrm{n}=25$ cows) was $3 \mathrm{~h}$ and $15 \mathrm{~min}$ for qPCR, and $12 \mathrm{~h}$ and 12 min for bacteriology (Table 4). The total cost (material and personnel) for an initial herd evaluation amounted to CHF293.60 for qPCR, whereas the total cost for the bacteriological approach was CHF1,063.35 (Table 4).

\section{DISCUSSION}

\section{Pilot Herds}

The first 2 phenomena were observed only in single cases during the sanitation of the 2 pilot herds, but they were considered during the official sanitation program as every transiently GTB-positive cow represents a risk factor for the transmission of Staph. aureus GTB to milking group 1. Cows were defined as transiently GTB-positive at the beginning of lactation (first phenomenon) if they resulted positive for Staph. aureus GTB during 1 or 2 consecutive samplings directly af-

Table 3. Overview of the GTB-specific cure and culling rates of infected cows in 19 dairy herds, which participated in a sanitation field study for Staphylococcus aureus genotype B (GTB)

\begin{tabular}{|c|c|c|c|}
\hline \multirow{2}{*}{$\begin{array}{l}\text { Sanitation group } \\
\text { and farm }\end{array}$} & \multicolumn{2}{|c|}{ GTB-specific } & \multirow[b]{2}{*}{ Difference $^{2}$} \\
\hline & Cure rate $^{3}$ & Culling rate ${ }^{4}$ & \\
\hline \multicolumn{4}{|l|}{ qPCR } \\
\hline 1 & $2 / 2(100)$ & $5 / 7(71)$ & 0 \\
\hline 2 & $2 / 3(67)$ & $2 / \mathbf{5}(40)$ & 1 \\
\hline 3 & $6 / 6(100)$ & $0 / 6(0)$ & 0 \\
\hline 4 & $2 / 2(100)$ & $4 / \mathbf{9}(44)$ & 3 \\
\hline 5 & $4 / 4(100)$ & $0 / 4(0)$ & 0 \\
\hline 6 & $25 / 25(100)$ & $9 / 44(20)$ & 10 \\
\hline 7 & $6 / 7(86)$ & $1 / 8(13)$ & 1 \\
\hline 8 & $10 / 14(71)$ & $4 / \mathbf{2 0}(20)$ & 6 \\
\hline 9 & $4 / 4(100)$ & $6 / 11(55)$ & 1 \\
\hline 10 & $1 / 1(100)$ & $0 / \mathbf{1}(0)$ & 0 \\
\hline $\operatorname{Median}^{5}(\%)$ & & 20 & \\
\hline \multicolumn{4}{|l|}{ Bacteriology } \\
\hline 11 & $10 / 10(100)$ & $3 / \mathbf{1 8}(17)$ & $3^{6}$ \\
\hline 12 & $5 / 5(100)$ & $0 / 5(0)$ & 0 \\
\hline 13 & $5 / 5(100)$ & $0 / 5(0)$ & 0 \\
\hline 14 & $1 / 1(100)$ & 0/1 (0) & 0 \\
\hline 15 & $3 / 3(100)$ & $0 / \mathbf{3}(0)$ & 0 \\
\hline 16 & $5 / 8(63)$ & $3 / 17(18)$ & $3^{6}$ \\
\hline 17 & $2 / 2(100)$ & $2 / 5(40)$ & $0^{6}$ \\
\hline 18 & $2 / 2(100)$ & $1 / 3(33)$ & 0 \\
\hline 19 & $25 / 25(100)$ & $4 / 29(14)$ & 0 \\
\hline $\operatorname{Median}^{5}(\%)$ & & 14 & \\
\hline
\end{tabular}

${ }^{1} \mathrm{qPCR}=$ sanitation group in which milk was analyzed by $\mathrm{qPCR}$; Bacteriology = sanitation group in which milk was analyzed by bacteriology.

${ }^{2}$ On farms 2, 4, 6, 7, 8, 9, 11, and 16, single GTB-positive cows were sold or moved to other farms during sanitation for fattening before slaughtering. This resulted in a difference between the total number of cows that tested positive for Staph. aureus GTB over all samplings (bold in the table), and the sum of successfully cured + culled cows.

${ }^{3}$ The GTB-specific cure rate represents the number of cows successfully treated by means of antibiotic therapy (during lactation or the dry period or both) divided by the total number of cows treated per farm over the 9-mo sanitation time, with percentages in parentheses.

${ }^{4}$ The GTB-specific culling rate represents the total number of cows culled (because GTB-positive) divided by the total number of cows tested positive for Staph. aureus GTB over all samplings, with percentages in parentheses (cows sampled positive several times were only counted once).

${ }^{5}$ For both sanitation groups, the median value is given for the GTB-specific culling rate of infected cows.

${ }^{6}$ For farms 11, 16, and 17, the GTB-positive cows still present on farm at sampling 9 were considered in the calculation of the difference. 
ter calving, but were GTB-negative during the rest of lactation (without treatment). Cows were defined as transiently GTB-positive at the end of lactation (second phenomenon) if they resulted positive for Staph. aureus GTB during 1 or 2 consecutive samplings before dry off but were GTB-negative during the whole previous lactation. The consequence of the first phenomenon was that all fresh cows had to be analyzed twice after calving, 2 to 3 and 4 to $5 \mathrm{wk}$ postpartum, respectively. In the meantime, fresh cows were kept in milking group 2 and milked after the GTB-negative cows. Only GTBnegative cows at both consecutive examinations were transferred to milking group 1. According to Persson Waller (2002) and Sordillo and Streicher (2002), several important immune functions are depressed around calving and causes are multifactorial. In particular, stress and high milk production are among the most important factors influencing the immunity of the mammary gland during the first months of lactation. Our hypothesis was that as soon as cows recovered their normal immune functionality after calving, infection could be kept under control, and consequently bacteria could not further spread in the mammary gland. Furthermore, the negative energy balance characterizing the metabolic status of dairy cows during the first months after calving (Esposito et al., 2014) could also increase the susceptibility to mastitis at the beginning of lactation. A last explanation could be that micro-abscesses, which sometimes wall-off Staph. aureus after establishment of infection in the mammary gland (Petersson-Wolfe et al., 2010), are partially deteriorated around calving so that bacteria can spread. The latter explanation could also lead to the second phenomenon, for which the consequence was that an antibiotic dry off therapy was applied to these cows, followed by a double control for Staph. aureus GTB at the beginning of the following lactation.

Considering the SCC of the GTB-positive cows in our study, our results are in line with previous studies that found cows infected with Staph. aureus do not necessarily have elevated SCC (Moret-Stalder et al., 2009; Petersson-Wolfe et al., 2010). In fact, consider-

Table 4. Comparison of the testing time and $\operatorname{cost}^{1}$ for the detection of Staphylococcus aureus genotype B (GTB) in milk by real-time quantitative PCR (qPCR) and classical bacteriology for the initial evaluation of a median Swiss dairy herd with 25 cows

\begin{tabular}{|c|c|c|c|c|c|}
\hline $\begin{array}{l}\text { Analytical } \\
\text { method }\end{array}$ & Analytical step & $\begin{array}{c}\text { Time }^{2} \\
\text { (hh:mm) }\end{array}$ & $\begin{array}{c}\text { Material cost }{ }^{3} \\
\quad(\mathrm{CHF})\end{array}$ & $\begin{array}{l}\text { Personnel cost } \\
\quad(\mathrm{CHF})\end{array}$ & $\begin{array}{c}\text { Total cost } \\
\text { (CHF) }\end{array}$ \\
\hline \multirow[t]{5}{*}{ qPCR } & Cow sampling (clean) & & & & \\
\hline & Preparation in the laboratory ${ }^{4}$ & 00:08 & 5.50 & $4.00^{5}$ & \\
\hline & Sample enrichment & $00: 18$ & 9.25 & $9.00^{5}$ & \\
\hline & DNA extraction & $01: 44$ & 131.45 & $52.00^{5}$ & \\
\hline & qPCR analysis ${ }^{8}$ & $00: 40$ & 54.90 & $20.00^{5}$ & \\
\hline \multirow{6}{*}{ Bacteriology } & Preparation in the laboratory ${ }^{4}$ & $00: 34$ & 11.00 & $17.00^{5}$ & \\
\hline & Farm & $00: 39^{6}$ & & $32.50^{9}$ & \\
\hline & Plates preparation & $01: 28$ & 160.30 & $44.00^{5}$ & \\
\hline & Plates evaluation (after $24 \mathrm{~h}$ ) & $00: 58$ & & $63.00^{10}$ & \\
\hline & Plates evaluation (after $48 \mathrm{~h}$ ) & $00: 25$ & & $26.65^{10}$ & \\
\hline & Total single analysis & 04:04 & 171.30 & 183.15 & 354.45 \\
\hline
\end{tabular}

${ }^{1}$ The present cost estimation considers exclusively the costs of material and personnel for both analytical methods applied during the field study and does not represent an overall economic evaluation of the whole sanitation procedure. In fact, other costs produced for example by wasted milk, antibiotic treatments, and culling of cows are not included in this calculation.

${ }^{2}$ Time required to perform the step of the analytical procedure.

${ }^{3}$ The material cost for each analytical step includes all consumables, media, and reagents used.

${ }^{4}$ Preparation of the material for cow sampling in the laboratory (labeling of sterile tubes).

${ }^{5}$ These analytical steps were carried out by a laboratory technician at an hourly rate of CHF30.00.

${ }^{6}$ Net time required on farm to sample 25 cows outside of a regular milking time. The driving time to reach the farm, the total milking time, and the time to pass from 1 cow to the next during sampling were not included because they were considered constant and equal for both methods.

${ }^{7}$ As sampling for qPCR can be performed by the farmer, this step is not included in the calculation of the cost for personnel.

${ }^{8}$ Amortization costs of the qPCR machine were $<1 \mathrm{CHF} /$ sample analyzed, over a time of $3 \mathrm{yr}$.

${ }^{9}$ Sterile sampling of cows of the bacteriology group was performed by a trained technician at an hourly rate of CHF50.00.

${ }^{10}$ Plates evaluation (after 24 and $48 \mathrm{~h}$ ) was carried out to $80 \%$ by a laboratory technician at an hourly rate of CHF 30.00 and to $20 \%$ by a specialist at an hourly rate of CHF200.00.

${ }^{11}$ Triple analysis of aseptically collected milk samples is required to reach sufficient diagnostic sensitivity for Staphylococcus aureus by phenotypical bacteriology (Sears et al., 1990; Studer et al., 2008; Kirchhofer et al., 2011). 
ing all herds participating to our sanitation program, $29 \%$ of the GTB-positive cows showed SCC within the physiologic limit $(<100,000$ cells $/ \mathrm{mL})$ at 1 st sampling. A possible explanation could be linked to the ability of Staph. aureus to evade the innate immune response of infected hosts (Rooijakkers et al., 2005; Oviedo-Boyso et al., 2007) and to persist intracellularly within mammary epithelial cells and neutrophils (Löffler et al., 2014; Peton and Le Loir, 2014). Additionally, fluctuations in the SCC values during the different stages of infection were also reported by Harmon (1994) for both minor and major pathogens, including Staph. aureus.

\section{Within-Herd Prevalence of Staph. aureus GTB During Sanitation}

Sixteen out of 19 farms (84\%) were sanitized until the end of the study. Three farms of the bacteriology group could not be completely sanitized during the 9 mo, but the analytical method used for milk sample analysis was not significant to explain the GTB prevalence on the farms at any time. Farms 11 and 17 concluded the study with 2 and 1 GTB-positive cows, respectively. In both cases, farmers decided to keep these cows on farm for economical or emotional reasons (high milk production, oldest cow on farm). Farm 16 represented an exception, and was characterized by a relatively high GTB prevalence at the end of the study. This farm showed a clear GTB prevalence increase at samplings 6 and 9 after an initial decrease. These new infections occurred during the summer season on communal alpine pastures (between the samplings 3 and 6), where the risk for new infections with Staph. aureus GTB is highly increased (up to 10 times; Berchtold et al., 2014). In fact, keeping a milking order is not always guaranteed on the alpine operation, and the milking procedures are often simplified in terms of equipment and hygiene (Voelk et al., 2014; van den Borne et al., 2017). After the end of the summer season, cows went back home, where new infections continued to take place in the following months, resulting in a GTB prevalence of $21 \%$ at the last sampling. As the GTB status of cows belonging to other farmers present on the same communal alpine operation was unknown, we recommended our farmers apply a kind of milking order during the time on alp; when it was not possible to create milking groups, we recommended milking cows with separate clusters to avoid new infections. Additionally, cows were sampled and analyzed for Staph. aureus (GTB) when they came back to their home farms after the end of the alpine season to promptly detect eventual new infections and give farmers the possibility to intervene. These measures enabled to avoid new infections on farms 13, 14, and 15 , which could maintain a GTB prevalence of zero during and after the alpine season. Furthermore, the single GTB-positive cows still present on farms 11 and 17 at the end of the sanitation program were intentionally kept on farm and were not the consequence of new infections occurred on the alp. Only farm 16 represented an exception, probably because the proposed alp-specific measures were not applied consistently. Taken together, these results indicate that a sanitation program for Staph. aureus GTB can also be successfully implemented when herds spend the summer season on alpine pastures (which is a very popular practice in Switzerland), with the premise that few alp-specific measures are strictly observed. However, because of the particular conditions present on alps, this practice can slow down the sanitation progress.

With a median herd size of 107 cows over all samplings, a particularly successful sanitation course could be observed for farm 6 (Table 2), which was the largest herd among all farms participating in our field study. In fact, the prevalence of Staph. aureus GTB decreased constantly during the sanitation time, ranging from $35 \%$ at 1 st sampling to $1 \%$ at sampling 7 (Table 2). From sampling 8, the herd was sanitized, and this status could be maintained also after the end of the official sanitation time, at least during the 5 monthly monitorings of the BTM. Farm 19 started the program with the highest GTB prevalence $(57 \%)$, reached a very low GTB prevalence at sampling 3, and was completely sanitized until the end of the study. The results of farm 6 (belonging to the qPCR group) and 19 (belonging to the bacteriology group) show that both analytical methods can support the successful sanitation of herds, even large ones. However, it should be noted that although they were large from a Swiss perspective (average herd size of a dairy farm $=25$ cows), farms 6 and 19 are below average for other countries (e.g., the United States, where the average herd size of a dairy farm was 223 cows in 2016; https://www .progressivepublish.com/downloads/2017/general/2016 -pd-stats-highres.pdf).

By comparing the bacteriological and $\mathrm{qPCR}$ results for herds of the bacteriology group, false-positive results were found at higher rates compared with the false negative. False-positive results were generated by cows infected with Staph. aureus genotypes other than GTB. In fact, in our study, all cows of the bacteriology group showing growth for Staph. aureus were classified as GTB-positive. This was the only approach enabling to detect all GTB-positive cows by bacteriology, as this method does not allow for the differentiation of genotypes. The unavoidable consequence was that in some cases the GTB prevalence was overestimated because Staph. aureus genotypes other than GTB were considered as GTB. This methodic limitation did not 
affect the final sanitation outcome negatively, but the consequence was that, in some cases, cows infected with a Staph. aureus genotype other than GTB were eventually treated or culled. False-negative results were found as isolated cases during our study and, given the typical cyclic shedding pattern of Staph. aureus, were probably due to the low bacterial amounts shed by some cows at the time of sampling, which could only be detected by qPCR because of its higher analytical sensitivity (Graber et al., 2007).

Considering the statistical analysis of the factors influencing the GTB prevalence, only the farmer's attitude showed an effect on the GTB prevalence at the end of the study. At sampling 3 and 6 , none of the included variables showed an effect on the GTB prevalence. Moreover, at sampling 6 , most of the farms had already reached either very low GTB prevalence or sanitation, and farmers showed increased confidence in the sanitation program. This can be explained by the fact that farms had reached a stable situation, without new infections, and farmers were therefore relieved. After sampling 6, farmers mostly needed external support because their active commitment toward the sanitation process started to decrease, probably due to a certain habituation effect. At sampling 9, the farmer's attitude was the only variable showing a highly significant effect on the GTB prevalence. In fact, very committed farmers (with a SFE value of 3) were able to make the efforts to reach sanitation independently, whereas the less committed ones (with a SFE value of 1 or 2) had to be continuously actively supported in doing this.

Our study showed that sanitation is possible for smaller and bigger farms, for tiestalls and freestalls, for different milking system types and cow breeds, for lower and higher initial GTB prevalence values, and also when cows spend the summer season on alpine pastures. In fact, none of these factors influenced the sanitation success. On the other hand, the ability to maintain a strict milking order was found to be decisive for the final sanitation outcome, and our active support (advice) during the whole sanitation time was often required to reach sanitation within 9 mo.

\section{GTB-Specific Cure and Culling Rates of Infected Cows}

According to previous studies, the cure rates of antibiotic therapy during lactation for subclinical Staph. aureus IMI are generally poor (Sol et al., 1997; Gruet et al., 2001; Barkema et al., 2006), with a median value of about 30\% (Gruet et al., 2001). Multiple hostlevel factors were shown to lead to lower cure rates; for example, higher parity, increased SCC, infection of multiple quarters, and longer lasting infection (Sol et al., 1997; Barkema et al., 2006). Therefore, based on this knowledge, we recommended a lactation therapy for GTB-positive cows in our field study, primarily for cows with a higher probability of cure (younger animals, low SCC, <200 DIM). Important adaptations in the treatment protocol were the extension of antibiotic administration to $5 \mathrm{~d}$ and the treatment of all quarters. According to Barkema et al. (2006), an extended antibiotic administration lead in most cases to increased cure rates for cows subclinically infected with Staph. aureus. This was probably one of the reasons leading to the very high overall cure rate (of 93\%) in our study (Table 3 ). The treatment of all quarters probably contributed to enhance the cure rates by avoiding the infection of further quarters, as GTB mostly infect multiple quarters of positive cows (Fournier et al., 2008) and the qPCR approach gives no information on which quarters are infected. This also agrees with Moret-Stalder et al. (2009), who found similar results for Staph. aureus. Additionally, it could be observed (from our own clinical experience) that sometimes cows that had been treated for Staph. aureus in single quarters later showed positive results in further quarters.

Ubrolexin was selected for the lactation therapy of GTB-positive cows during our sanitation program; this preparation contains a combination of kanamycin (aminoglycoside) and cephalexin (first-generation cephalosporin). This drug was chosen based on our own bioinformatics results, which excluded the presence of genes coding for aminoglycosides resistance in the genome of multiple Staph. aureus GTB strains (unpublished data). This was also confirmed by a study conducted in Switzerland by Overesch et al. (2013), who found that only $1.7 \%$ of the totally analyzed Staph. aureus strains $(\mathrm{n}=287)$ were resistant to the aminoglycosides kanamycin and gentamycin. A similar product available in Switzerland is Gentapen (Dr. E. Graeub AG, Bern, Switzerland), which contains gentamycin (aminoglycoside) combined with penicillin. Ubrolexin was preferred because this product was only registered recently, whereas Gentapen has been available for more than 30 yr. Additionally, Ubrolexin is registered for use once daily and not twice daily, which made treatment easier.

The GTB-specific culling rate of infected cows varied between 0 and $71 \%$, depending on the farm (Table 3). The correspondent median value was slightly higher for the qPCR group (20\%) compared with the bacteriology group (14\%), but the culling rate can still be considered similar in the 2 sanitation groups (Table 3 ). The elimination of GTB-positive cows followed 2 main patterns: (1) cows without a particular genetic, economic, or emotional value were culled early, without any therapy attempt; and (2) particularly valuable cows were culled later, in some cases after 1 or more unsuccessful therapy 
attempts. In this case, the decision to cull a cow was made when the risk of new infections was perceived by the farmer as higher than the loss caused by the elimination of the animal. The decision time varied depending on the farmer's attitude, on the value of the chronically infected cow, and on its gestation status. Additionally, single GTB-positive cows (0 to 10 per farm; Table 3) were sold or moved to other farms during sanitation for fattening before slaughtering, explaining the differences between the total number of cows tested positive for Staph. aureus GTB per farm over all samplings and the sum of successfully treated and culled cows.

\section{SCC During Sanitation}

Some peculiarities could be observed in the BMSCC pattern of single farms over the sanitation time (Figure 2). Farms 3 and 12 showed very low BMSCC levels over the whole sanitation time. These farms were characterized by an excellent SFE value, which enabled them to keep the BMSCC stable at a very low level despite having a contagious udder pathogen in the herd. After having started the sanitation program with GTB prevalences of 25 and $20 \%$, respectively, herds 3 and 12 reached a GTB prevalence of zero early in the study (before the 3rd sanitation month), confirming the high commitment of these farmers toward the sanitation program.

As expected from the sanitation program as a consequence of the progressive eradication of Staph. aureus GTB, farms 4, 5, 6, 8, 11, and 19 showed an overall decrease of the BMSCC during the sanitation time, reaching low values (farms $4,5,11$, and $19<100,000$ cells/mL, and farms 6 and $8<130,000$ cells $/ \mathrm{mL}$ ) at last sampling in particular. Out of all farms, farm 19 showed the most drastic decrease of BMSCC after the 1st sampling, which could be maintained below 80,000 cells $/ \mathrm{mL}$ until the end of the program. This was also the only farm showing a surprisingly parallel course of GTB prevalence and BMSCC, meaning that the high SCC level of this farm at the beginning of the program (341,439 cells/mL) was due to the presence of Staph. aureus GTB.

Farms 2 and 7 showed a stable, but relatively high BMSCC level over the whole sanitation time, also after having reached a very low or zero GTB prevalence. These 2 farms show that the eradication of Staph. aureus GTB does not necessarily involve a simultaneous decrease of the BMSCC. In fact, other mastitis pathogens that also influence this parameter could be present on farm, and these are not controlled by the sanitation program, which primarily aimed to eliminate Staph. aureus GTB from the milking herd.
The particular zig-zag pattern characterizing farms $1,9,10,13,14,15,16,17$, and 18 can be explained by the fact that these farms spent the summer season on communal alpine operations. Except for farm 9, for which a peak in the BMSCC value was observed at the beginning of the alpine period, all other farms $(1,10$, $13,14,15,16,17$, and 18) peaked directly after the end of the alpine period, which corresponds to the month of September. Due to the staggered start of the sanitation program for the different herds, the end of the alpine period corresponds to sampling 6 for herds 1, 15, and 16 and to sampling 9 for herds 10, 13, 14, 17, and 18 . During the time in the mountains, cows from different herds of origin are generally commingled, pastured at higher altitudes, and milked together (Voelk et al., 2014; Sartori et al., 2017; van den Borne et al., 2017), and these additional stress factors could explain the BMSCC peaks characterizing these farms. Furthermore, these farms practiced seasonal calving, which is typical for some Swiss mountainous regions (van den Borne et al., 2017), and the majority of cows were approaching the dry off period at the time of the BMSCC peak. In fact, an increase of the SCC can generally be observed toward the end of lactation, particularly when cows are subclinically infected with mastitis pathogens or when the dilution effect is lost, because milk production drops below $4 \mathrm{~kg} / \mathrm{d}$ (Harmon, 1994). For these farms, the effect of the alpine pasturing on the BMSCC course was probably predominant, so that a possible positive effect of sanitation on the BMSCC could generally be observed only at the sampling 3, before the start of the alpine season (Figure 2). Farm 13 was the only exception showing a drastic BMSCC increase at the last sampling due to the very limited number of cows still lactating at this time $(\mathrm{n}=6)$. For farms 1,15 , and 16 , a second clear decrease in the BMSCC was also observed at last sampling, which was carried out 3 mo after the end of the alpine season.

\section{Comparison of Testing Time and Detection Cost for GTB in Milk by qPCR and Bacteriology}

Considering that a triple analysis of milk samples is required to reach sufficient diagnostic sensitivity for Staph. aureus by bacteriology (Sears et al., 1990; Studer et al., 2008; Kirchhofer et al., 2011), the total analysis time for the complete first evaluation of a median Swiss herd using this method was 3.8 times higher than by using qPCR (Table 4). For this calculation, we only considered the time during which operators actively worked on farm to sample cows or in the laboratory until the final result was obtained. In particular, the driving time to reach the farm, the total milking time, 
and the time to pass from one cow to the next during sampling were not included because they were considered constant and equal for both methods. Incubation times were also not included; nevertheless, it should be noted that the qPCR method requires a unique incubation step of $18 \mathrm{~h}$ for bacterial enrichment, whereas the bacteriology method requires 2 incubation steps of 24 $\mathrm{h}$ to obtain conclusive results, and this additional day should be taken into account when comparing the total analysis time. The sampling time for a single bacteriological analysis of a median herd was 4.1 times higher than for qPCR. In fact, individual quarters need to be sampled for bacteriology and the aseptic cleaning procedure is more time-consuming than the clean one.

Although the most important costs caused by mastitis are associated with the culling (and replacement) of infected animals, antibiotic treatment and the subsequently wasted milk, and production losses (Halasa et al., 2007; Hogeveen et al., 2011), the present economic calculation specifically aimed to compare only the testing costs for the detection of Staph. aureus GTB in milk during a sanitation program using 2 different analytical methods. Whereas the material cost was higher for the qPCR method than for a single bacteriological analysis of a median herd (CHF201.10 vs. CHF171.30), the cost for personnel turned out to be clearly higher $(2.0$ times) for a single bacteriological analysis compared with qPCR (Table 4). This difference was mainly due to the labor-intensive aseptic sampling procedure for bacteriology, requiring the experience of a trained technician, and to the evaluation of bacteriological results, which required the experience of a specialist (Table 4). On the other hand, clean samples for qPCR analysis can be collected by the farmers themselves, resulting in a complete saving of the sampling costs and the whole analytical procedure can be performed and evaluated by a laboratory technician. Considering a triple bacteriological analysis and the total analysis cost, the price difference between the 2 methods corresponded to a factor of 3.6. However, in Switzerland the collection of sterile milk samples for bacteriological analysis is typically performed by a veterinarian, increasing the personnel cost for sterile sampling from CHF32.50 (Table 4) to CHF130.00. This results in an even higher price difference between the 2 analytical methods (factor of 4.6).

\section{Comparison of Bacteriology and qPCR During Sanitation Programs for GTB}

Although the successful sanitation of Staph. aureus GTB-positive herds was possible using both analytical methods, the qPCR approach showed some important advantages, which highly facilitate the practical appli- cation of the sanitation program, compared with classical bacteriology. The sampling procedure (collection of clean composite samples) can be performed by the farmer during a normal milking procedure, which enables sampling even on large farms without additional personnel. In contrast, the aseptic collection of singlequarter milk samples for bacteriology is time-consuming and has to be performed by a trained technician, causing additional costs (Table 4).

The lower limit of detection characterizing the qPCR approach for Staph. aureus enables to minimize the rate of false-negative results, which could lead to new infections in the herd (Graber et al., 2007; Sartori et al., 2017). Furthermore, the very high analytical specificity of the qPCR assay enables specific targeting of only the genotype of interest (Sartori et al., 2017).

The qPCR approach enables a much faster allocation of cows to the milking groups, with conclusive results already after the 1st sampling; this enables a continuous update of the milking order, thereby accelerating the overall sanitation procedure. In contrast, the first complete evaluation of a cow by classical bacteriology lasts at least $1 \mathrm{mo}$, and this extended time interval represents a risk for new infections in the herd. Furthermore, as triple sampling is required to reach enough diagnostic sensitivity for Staph. aureus (95\%) by bacteriology (Sears et al., 1990; Studer et al., 2008; Kirchhofer et al., 2011), this method is inconvenient for the sanitation of big herds in the field.

Finally, our calculations revealed that the qPCR method is advantageous for the analysis of milk samples both in terms of total analysis time and cost, compared with classical culture methods. Taken together, all the technical advantages of $\mathrm{qPCR}$ render this approach highly suitable for routine application during sanitation programs for Staph. aureus GTB and in times of high sample throughputs (Sartori et al., 2017). Although sanitation can also be achieved using bacteriology, this analytical approach is reasonable only for small farms (up to 30 cows), as both the sterile sampling procedure and the evaluation of laboratory results are very timeconsuming and cost-intensive (Table 4).

\section{CONCLUSIONS}

The present longitudinal field study demonstrated that Staph. aureus GTB-positive dairy herds can be successfully sanitized by the appropriate measures, in particular the keeping of a correct and strict milking order, proper milking hygiene, appropriate antibiotic therapy of eligible cows, and culling of chronically infected, therapy-resistant cows. As methods for milk sample analysis, classical bacteriology and the qPCR assay by Sartori et al. (2017) are both suitable, but the 
latter shows advantages regarding sampling procedure, test time and cost, and specificity for the contagious genotype GTB of Staph. aureus.

\section{ACKNOWLEDGMENTS}

We thank all farmers for their cooperation during our field study, Daniel Dietrich (Schweizerische Arbeitsgemeinschaft für klinische Krebsforschung SAKK, Berne, Switzerland) for statistical support, and both Swiss breeding associations (Braunvieh Schweiz, Zug, Switzerland, and swissherdbook, Zollikofen, Switzerland) for having made SCC data available. Moreover, we thank Adrian Steiner (Clinic for Ruminants, Berne, Switzerland), Martin Reist (Federal Food Safety and Veterinary Office, Berne, Switzerland), and Gertraud Schüpbach (Veterinary Public Health Institute, Berne, Switzerland) for valuable support during study design. The study was supported by a grant of the Federal Office for Agriculture (FOAG, Berne, Switzerland).

\section{REFERENCES}

Balaban, N., and A. Rasooly. 2000. Review: Staphylococcal enterotoxins. Int. J. Food Microbiol. 61:1-10.

Barkema, H. W., Y. H. Schukken, and R. N. Zadoks. 2006. Invited review: The role of cow, pathogen, and treatment regimen in the therapeutic success of bovine Staphylococcus aureus mastitis. J. Dairy Sci. 89:1877-1895.

Berchtold, B., M. Bodmer, B. H. van den Borne, M. Reist, H. U. Graber, A. Steiner, R. Boss, and F. Wohlfender. 2014. Genotypespecific risk factors for Staphylococcus aureus in Swiss dairy herds with an elevated yield-corrected herd somatic cell count. J. Dairy Sci. 97:4886-4896.

Boss, R., J. Naskova, A. Steiner, and H. U. Graber. 2011. Mastitis diagnostics: Quantitative PCR for Staphylococcus aureus genotype B in bulk tank milk. J. Dairy Sci. 94:128-137.

Carrillo-Casas, E. M., and R. E. Miranda-Morales. 2012. Bovine mastitis pathogens: Prevalence and effects on somatic cell count. Pages 359-374 in Milk Production-An Up-to-Date Overview of Animal Nutrition, Management and Health. N. Chaiyabutr, ed. InTech, London, UK. Accessed Jul. 25, 2017. https://www.intechopen .com/books/milk-production-an-up-to-date-overview-of-animal -nutrition-management-and-health/bovine-mastitis-pathogens -prevalence-and-effects-on-somatic-cell-count.

Cosandey, A., R. Boss, M. Luini, K. Artursson, M. Bardiau, F. Breitenwieser, E. Hehenberger, T. Lam, M. Mansfeld, A. Michel, G. Mosslacher, J. Naskova, S. Nelson, O. Podpecan, A. Raemy, E. Ryan, O. Salat, P. Zangerl, A. Steiner, and H. U. Graber. 2016. Staphylococcus aureus genotype B and other genotypes isolated from cow milk in European countries. J. Dairy Sci. 99:529-540.

Cremonesi, P., F. Pozzi, M. Raschetti, G. Bignoli, E. Capra, H. U. Graber, F. Vezzoli, R. Piccinini, B. Bertasi, S. Biffani, B. Castiglioni, and M. Luini. 2015. Genomic characteristics of Staphylococcus aureus strains associated with high within-herd prevalence of intramammary infections in dairy cows. J. Dairy Sci. 98:6828-6838.

Esposito, G., P. C. Irons, E. C. Webb, and A. Chapwanya. 2014. Review article: Interactions between negative energy balance, metabolic diseases, uterine health and immune response in transition dairy cows. Anim. Reprod. Sci. 144:60-71.

Fournier, C., P. Kuhnert, J. Frey, R. Miserez, M. Kirchhofer, T. Kaufmann, A. Steiner, and H. U. Graber. 2008. Bovine Staphylococcus aureus: association of virulence genes, genotypes and clinical outcome. Res. Vet. Sci. 85:439-448.
Graber, H. U., M. G. Casey, J. Naskova, A. Steiner, and W. Schaeren. 2007. Development of a highly sensitive and specific assay to detect Staphylococcus aureus in bovine mastitic milk. J. Dairy Sci. 90:4661-4669.

Gruet, P., P. Maincent, X. Berthelot, and V. Kaltsatos. 2001. Bovine mastitis and intramammary drug delivery: Review and perspectives. Adv. Drug Deliv. Rev. 50:245-259.

Halasa, T., K. Huijps, O. Østerås, and H. Hogeveen. 2007. Economic effects of bovine mastitis and mastitis management: A review. Vet. Q. 29:18-31.

Halasa, T., M. Nielen, A. P. De Roos, R. Van Hoorne, G. de Jong, T. J. Lam, T. van Werven, and H. Hogeveen. 2009. Production loss due to new subclinical mastitis in Dutch dairy cows estimated with a test-day model. J. Dairy Sci. 92:599-606.

Harmon, R. J. 1994. Physiology of mastitis and factors affecting somatic cell counts. J. Dairy Sci. 77:2103-2112.

Hogeveen, H., K. Huijps, and T. J. Lam. 2011. Economic aspects of mastitis: New developments. N. Z. Vet. J. 59:16-23.

Hummerjohann, J., J. Naskova, A. Baumgartner, and H. U. Graber. 2014. Enterotoxin-producing Staphylococcus aureus genotype B as a major contaminant in Swiss raw milk cheese. J. Dairy Sci. 97:1305-1312.

Kirchhofer, M., T. Kaufmann, M. Guelat-Brechbuhl, A. Michel, C. Syring, and M. Bodmer. 2011. Systematic sanitation of dairy herds with mastitis caused by Staphylococcus aureus. Schweiz. Arch. Tierheilkd. 153:361-368.

Koskinen, M. T., G. J. Wellenberg, O. C. Sampimon, J. Holopainen, A. Rothkamp, L. Salmikivi, W. A. van Haeringen, T. J. Lam, and S. Pyörälä. 2010. Field comparison of real-time polymerase chain reaction and bacterial culture for identification of bovine mastitis bacteria. J. Dairy Sci. 93:5707-5715.

Kümmel, J., B. Stessl, M. Gonano, G. Walcher, O. Bereuter, M. Fricker, T. Grunert, M. Wagner, and M. Ehling-Schulz. 2016. Staphylococcus aureus entrance into the dairy chain: Tracking $S$. aureus from dairy cow to cheese. Front. Microbiol. 7:1603.

Lam, T. J., B. H. van den Borne, J. Jansen, K. Huijps, J. C. van Veersen, G. van Schaik, and H. Hogeveen. 2013. Improving bovine udder health: A national mastitis control program in the Netherlands. J. Dairy Sci. 96:1301-1311.

Landin, H., M. J. Mork, M. Larsson, and K. P. Waller. 2015. Vaccination against Staphylococcus aureus mastitis in two Swedish dairy herds. Acta Vet. Scand. 57:81.

Löffler, B., L. Tuchscherr, S. Niemann, and G. Peters. 2014. Staphylococcus aureus persistence in non-professional phagocytes. Int. J. Med. Microbiol. 304:170-176.

Moret-Stalder, S., C. Fournier, R. Miserez, S. Albini, M. G. Doherr, M. Reist, W. Schaeren, M. Kirchhofer, H. U. Graber, A. Steiner, and T. Kaufmann. 2009. Short communication: Prevalence study of Staphylococcus aureus in quarter milk samples of dairy cows in the Canton of Bern, Switzerland. Prev. Vet. Med. 88:72-76.

Neave, F. K., F. H. Dodd, R. G. Kingwill, and D. R. Westgarth. 1969. Control of mastitis in the dairy herd by hygiene and management. J. Dairy Sci. 52:696-707.

NMC (National Mastitis Council). 1999. Laboratory Handbook on Bovine Mastitis. Rev. ed., National Mastitis Council Inc., Madison, WI.

Osterås, O., and L. Sølverød. 2009. Norwegian mastitis control programme. Ir. Vet. J. 62(Suppl. 4):S26-33.

Overesch, G., R. Stephan, and V. Perreten. 2013. Antimicrobial susceptibility of gram-positive udder pathogens from bovine mastitis milk in Switzterland. Schweiz. Arch. Tierheilkd. 155:339-350.

Oviedo-Boyso, J., J. J. Valdez-Alarcón, M. Cajero-Juárez, A. OchoaZarzosa, J. E. López-Meza, A. Bravo-Patiño, and V. M. Baizabal-Aguirre. 2007. Innate immune response of bovine mammary gland to pathogenic bacteria responsible for mastitis. J. Infect. 54:399-409.

Paulin, S., B. Horn, and J. A. Hudson. 2011. Factors influencing staphylococcal enterotoxin production in dairy products. MPI Technical. Ministry for Primary Industries, Wellington, New Zeeland.

Persson Waller, K. 2002. Mammary gland immunology around parturition. Influence of stress, nutrition and genetics. Pages 231-245 
in Biology of the Mammary Gland. Advances in Experimental Medicine and Biology. J. A. Mol, and R. A. Clegg, ed. Springer, Boston, MA.

Petersson-Wolfe, C. S., I. K. Mullarky, and G. M. Jones. 2010. Staphylococcus aureus mastitis: Cause, detection, and control. Virginia Cooperative Extension:1-7. Accessed Jul. 18, 2017. https://www .pubs.ext.vt.edu/404/404-229/404-229.html.

Peton, V., and Y. Le Loir. 2014. Staphylococcus aureus in veterinary medicine. Infect. Genet. Evol. 21:602-615.

R Core Team. 2017. R: A Language and Environment for Statistical Computing. R Foundation for Statistical Computing, Vienna, Austria. https://www.R-project.org/.

Rooijakkers, S. H., K. P. van Kessel, and J. A. van Strijp. 2005. Staphylococcal innate immune evasion. Trends Microbiol. 13:596-601.

Sartori, C., R. Boss, I. Ivanovic, and H. U. Graber. 2017. Development of a new real-time quantitative PCR assay for the detection of Staphylococcus aureus genotype B in cow milk, targeting the new gene adlb. J. Dairy Sci. 100:7834-7845.

Schukken, Y. H., V. Bronzo, C. Locatelli, C. Pollera, N. Rota, A. Casula, F. Testa, L. Scaccabarozzi, R. March, D. Zalduendo, R. Guix, and P. Moroni. 2014. Efficacy of vaccination on Staphylococcus aureus and coagulase-negative staphylococci intramammary infection dynamics in 2 dairy herds. J. Dairy Sci. 97:5250-5264.

Sears, P. M., and K. K. McCarthy. 2003. Management and treatment of staphylococcal mastitis. Vet. Clin. North Am. Food Anim. Pract. 19:171-185.

Sears, P. M., B. S. Smith, P. B. English, P. S. Herer, and R. N. Gonzalez. 1990. Shedding pattern of Staphylococcus aureus from bovine intramammary infections. J. Dairy Sci. 73:2785-2789.
Sol, J., O. C. Sampimon, H. W. Barkema, and Y. H. Schukken. 2000 Factors associated with cure after therapy of clinical mastitis caused by Staphylococcus aureus. J. Dairy Sci. 83:278-284.

Sol, J., O. C. Sampimon, J. J. Snoep, and Y. H. Schukken. 1997. Factors associated with bacteriological cure during lactation after therapy for subclinical mastitis caused by Staphylococcus aureus. J. Dairy Sci. 80:2803-2808.

Sordillo, L. M., and K. L. Streicher. 2002. Mammary gland immunity and mastitis susceptibility. J. Mammary Gland Biol. Neoplasia $7: 135-146$

Studer, E., W. Schaeren, J. Naskova, H. Pfaeffli, T. Kaufmann, M. Kirchhofer, A. Steiner, and H. U. Graber. 2008. A longitudinal field study to evaluate the diagnostic properties of a quantitative real-time polymerase chain reaction-based assay to detect Staphylococcus aureus in milk. J. Dairy Sci. 91:1893-1902.

Syring, C., R. Boss, M. Reist, M. Bodmer, J. Hummerjohann, P. Gehrig, and H. U. Graber. 2012. Bovine mastitis: The diagnostic properties of a PCR-based assay to monitor the Staphylococcus aureus genotype B status of a herd, using bulk tank milk. J. Dairy Sci. 95:3674-3682.

van den Borne, B. H., H. U. Graber, V. Voelk, C. Sartori, A. Steiner, M. C. Haerdi-Landerer, and M. Bodmer. 2017. A longitudinal study on transmission of Staphylococcus aureus genotype B in Swiss communal dairy herds. Prev. Vet. Med. 136:65-68.

Voelk, V., H. U. Graber, B. H. van den Borne, C. Sartori, A. Steiner, M. Bodmer, and M. C. Haerdi-Landerer. 2014. A longitudinal study investigating the prevalence of Staphylococcus aureus genotype B in seasonally communal dairy herds. J. Dairy Sci. 97:4184-4192. 